\title{
Volume-Activated Chloride Currents Contribute to the Resting Conductance and Invasive Migration of Human Glioma Cells
}

\author{
Christopher B. Ransom, Jeffrey T. O'Neal, and Harald Sontheimer \\ Department of Neurobiology, University of Alabama at Birmingham, Birmingham, Alabama 35294
}

\begin{abstract}
We used an in vitro model for glioma cell invasion (transwell migration assay) and patch-clamp techniques to investigate the role of volume-activated $\mathrm{Cl}^{-}$currents $\left(I_{\mathrm{CI}, \mathrm{Vol}}\right)$ in glioma cell invasion. Hypotonic solutions $(\approx 230 \mathrm{mOsm})$ activated outwardly rectifying currents that reversed near the equilibrium potential for $\mathrm{Cl}^{-}$ions $\left(E_{\mathrm{Cl}}\right)$. These currents $\left(I_{\mathrm{Cl}, \mathrm{Vol}}\right)$ were sensitive to several known $\mathrm{Cl}^{-}$channel inhibitors, including DIDS, tamoxifen, and 5-nitro-2-(3-phenylpropylamino)-benzoate (NPPB). The $\mathrm{IC}_{50}$ for NPPB inhibition of $I_{\mathrm{Cl} \text {,Vol }}$ was $21 \mu \mathrm{m}$. Under isotonic conditions, NPPB $(165 \mu \mathrm{M})$ blocked inward currents (at $-40 \mathrm{mV}$ ) and increased input resistance in both standard whole-cell recordings and amphotericin perforated-patch recordings. Reducing $\left[\mathrm{Cl}^{-}\right]_{0}$ under isotonic conditions positively shifted the reversal potential of whole-cell currents. These findings suggest a significant resting $\mathrm{Cl}^{-}$conductance in glioma cells. Under isotonic and hypotonic conditions, $\mathrm{Cl}^{-}$channels
\end{abstract}

displayed voltage- and time-dependent inactivation and had an $\mathrm{I}^{-}>\mathrm{Cl}^{-}$permeability. To assess the potential role of these channels in cell migration, we studied the chemotactic migration of glioma cells toward laminin or vitronectin in a Boyden chamber containing transwell filters with $8 \mu \mathrm{m}$ pores. Inhibition of $I_{\mathrm{CI}, \mathrm{Vol}}$ with NPPB reduced chemotactic migration in a dosedependent fashion with an $\mathrm{IC}_{50}$ of $27 \mu \mathrm{M}$. Time-lapse video microscopy during patch-clamp recordings revealed visible changes in cell shape and/or movement that accompanied spontaneous activation of $I_{\mathrm{Cl}, \mathrm{Vol}}$, suggesting that $I_{\mathrm{Cl}, \mathrm{Vol}}$ is activated during cell movement, consistent with the effects of NPPB in migration assays. We propose that $I_{\mathrm{Cl}, \mathrm{Vol}}$ contributes to cell shape and volume changes required for glioma cell migration through brain tissue.

Key words: brain tumor; volume regulation; $\mathrm{Cl}^{-}$channels; ion channels; neuro-oncology; extracellular matrix
Chloride channels are ubiquitous transmembrane proteins involved in diverse cellular processes. They are essential for salt and fluid movements across epithelia (Venglarik et al., 1990; O'Grady et al., 2000), volume regulation (Jackson and Madsen, 1997; Valverde, 1999), and they contribute to the proliferation of some cell types (Wilson and Chiu, 1993; Pappas and Ritchie, 1998; Shen et al., 2000). We previously proposed that the invasive migration of human glioma cells requires shape and/or volume changes (Soroceanu et al., 1999). Chloride currents may contribute to such shape-volume changes by affecting net salt fluxes across glioma membranes. We hypothesize that salt efflux, with its accompanying water efflux, results in cell shrinkage that is conducive to glioma cell migration through the minute extracellular spaces of brain. Hence, chloride channels may aid the invasive biology of glioma cells, a feature that greatly compromises surgical treatment of this disease (Adams and Victor, 1989).

Recently, a significant effort has gone into the molecular identification of diverse chloride channels (Valverde, 1999; Maduke et al., 2000). However, one of the most ubiquitously expressed channels, the one mediating volume-activated chloride currents $\left(I_{\mathrm{Cl}, \mathrm{Vol}}\right)$, has been elusive. Although some studies suggest that $I_{\mathrm{Cl}, \mathrm{Vol}}$ is mediated by ClC-3 $\mathrm{Cl}^{-}$channels (Duan et al., 1997, 1999; Wang et al., 2000), a recent study found no deficit of volume-activated chloride currents in hepatocytes from $\mathrm{ClC}-3$

Received March 12, 2001; revised July 13, 2001; accepted July 20, 2001.

This work was supported by National Institutes of Health Grant RO1NS36692, American Cancer Society Grant ACS-RPG-083-01CDD, and a Medical Scientist Training Program scholarship (C.B.R.).

Correspondence should be addressed to Dr. Harald Sontheimer, Department of Neurobiology, University of Alabama at Birmingham, 1719 Sixth Avenue, S CIRC 545, Birmingham, AL 35294. E-mail: hws@nrc.uab.edu.

Copyright (C) 2001 Society for Neuroscience $0270-6474 / 01 / 217674-10 \$ 15.00 / 0$ knock-out mice (Stobrawa et al., 2001). In spite of the difficulties concerning the molecular identification of $I_{\mathrm{Cl} \text {,Vol }}$, there is good agreement on the properties of endogenous volume-activated chloride currents (Rasola et al., 1992; Diaz et al., 1993; Pollard, 1993; Bond et al., 1998a; Duan et al., 1999; Von Weikersthal et al., 1999; Shen et al., 2000). Hallmark properties of these currents include slight outward-rectification, time- and voltage-dependent inactivation at positive potentials, and block by tamoxifen, 5-nitro-2-(3-phenylpropylamino)-benzoate (NPPB), DIDS, and $\mathrm{Zn}^{2+}$. In addition, $I_{\mathrm{Cl} \text {,Vol }}$ has a halide selectivity sequence of $\mathrm{I}^{-}$ $>\mathrm{Br}^{-}>\mathrm{Cl}^{-}>\mathrm{F}^{-}$(Rasola et al., 1992; Diaz et al., 1993; Bond et al., 1998a; Duan et al., 1999; Von Weikersthal et al., 1999; Shen et al., 2000). $I_{\mathrm{Cl}, \mathrm{Vol}}$ is believed to be essential for volume regulation of cells, particularly after cell swelling with hypotonic solutions (Jackson and Madsen, 1997; Rouzaire-Dubois et al., 1999; Valverde, 1999; Wang et al., 2000). The activation of $I_{\mathrm{Cl} \text {, Vol }}$ by volume changes and its influence on cell volume make it a prime candidate for participation in the shape-volume changes that glioma cells undergo during invasive migration (Soroceanu et al., 1999). We used patch-clamp techniques to investigate $\mathrm{Cl}^{-}$currents in human glioma cells and an in vitro model of invasive migration (transwell migration assay) to evaluate their role in invasion. We find that the resting conductance of human glioma cells is dominated by chloride channels with a pharmacology consistent with that of $I_{\mathrm{Cl}, \mathrm{Vol}}$. Furthermore, inhibitors of $I_{\mathrm{Cl}, \mathrm{Vol}}$ block the migration of glioma cells.

\section{MATERIALS AND METHODS}

Cell culture. All experiments were performed on the glioma cell lines STTG-1 (anaplastic astrocytoma, WHO grade III; American Type Tissue Collection, Rockville, MD) and D54MG (glioblastoma multiforme, WHO grade IV; Dr. D. Bigner, Duke University, Durham, NC). Cells 
were maintained in DMEM (Life Technologies, Grand Island, NY) with $10 \%$ fetal calf serum (Hyclone, Logan, UT). Cells were kept in an incubator (Lab-Line Instruments, Melrose Park, IL) at $37^{\circ} \mathrm{C}$ in a $90 \%$ $\mathrm{O}_{2} / 10 \% \mathrm{CO}_{2}$ humidified environment.

Electrophysiology. Standard patch-clamp techniques were used to record whole-cell membrane currents (Hamill et al., 1981). Patch pipettes were pulled on an upright puller (PP-83; Narishige, Tokyo, Japan) from thin-walled, glass capillary tubing with filament (MTW150F-4; WPI, Sarasota, FL) and had resistances of 3-5 M 2 . For experiments with amphotericin B (Sigma, St. Louis, MO) perforated patches, we closely followed the procedures of Rae et al. (1991). Pipettes used for amphotericin perforated-patch recording were fire-polished on a microforge (MF-83, Narishige) and had resistances of 1-3 M $\Omega$. Inclusion of Lucifer yellow (Sigma) in our pipette solutions for amphotericin perforatedpatch recordings allowed us to distinguish perforated-patch recordings from whole-cell recordings (fluorescence rapidly appeared in cells after breakthrough). We used an Axopatch 200B amplifier (Axon Instruments, Redwood City, CA) controlled by a PC-compatible microcomputer (Dell Computers, Dallas, TX) running Axon Instruments software (pClamp7). Data were stored directly to disk using a Digidata 1200 A-D interface (Axon Instruments). Data were acquired at $10 \mathrm{kHz}$ and filtered at $2 \mathrm{kHz}$. Capacitance and series resistance, $R_{\mathrm{s}}$, compensation was performed with the Axopatch amplifier. $R_{\mathrm{s}}$ was compensated up to $80 \%$. No post hoc correction of $R_{\mathrm{s}}$ was performed. Experiments were not performed on cells with a $R_{\mathrm{s}}>10 \mathrm{M} \Omega$ (except with amphotericin perforated patches). Cells were visualized with an inverted microscope (Nikon, Melville, NY). The recording chamber had a volume of $\approx 300 \mu \mathrm{l}$ and was constantly superfused with control extracellular solution at a rate of $\approx 0.5$ $\mathrm{ml} / \mathrm{min}$. A triple-barreled microperfusion device with a stepper motor (SF-77B perfusion fast-step; Warner Instruments, Hamden, CT) was used to apply test solutions directly to cells. Grounding the recording chamber via an agar salt bridge (4\% agar, $1 \mathrm{M} \mathrm{KCl})$ minimized liquid junction potentials produced by test solutions.

Solutions. Our standard bath solution contained the following (in $\mathrm{mm}$ ): $5 \mathrm{KCl}, 135 \mathrm{NaCl}, 1.6 \mathrm{Na}_{2} \mathrm{HPO}_{4}, 0.4 \mathrm{NaH}_{2} \mathrm{PO}_{4}, 1 \mathrm{MgSO}_{4}, 10$ glucose, 32.5 HEPES (acid). pH was adjusted to 7.4 with $\mathrm{NaOH}$. Osmolarity was tested with a vapor pressure osmometer (Wescor 5500; Wescor, Logan, UT). The osmolarity of control bath solution was $\approx 300 \mathrm{mOsm}$. Solutions were made hypotonic by mixing control bath solution with bath solution with no added $\mathrm{NaCl}$. Drugs were added directly to these solutions. $\mathrm{Cl}^{-}$ currents were isolated pharmacologically by adding 1-10 mM tetraethylammonium ion (TEA) to our bath solution to inhibit the big conductance $\mathrm{K}$ (BK) channels in these cells (Fig. 3). Our standard pipette solution contained (in mM): $145 \mathrm{CsCl}, 1 \mathrm{MgCl}_{2}, 10 \mathrm{HEPES}$ (acid), and 10 EGTA. We used KCl-based pipette solutions for perforated-patch experiments and when we pharmacologically isolated chloride currents. pH was adjusted to 7.25 with Tris-base. All chemicals were purchased from Sigma unless otherwise noted.

Transwell migration assays. To assess chloride current involvement in glioma cell migration, we performed transwell migration assays, an in vitro model for invasive migration. Briefly, cells were plated on top of a culture plate insert (Becton Dickinson, Rutherford, NJ). The insert consists of a filter with $8 \mu \mathrm{m}$ pores that cells must navigate to cross to the bottom side of the transwell filter. Assays were run for $\approx 4 \mathrm{hr}$ in serumfree culture media (DMEM) at $37^{\circ} \mathrm{C}$ in a humidified $90 \% \mathrm{O}_{2} / 10 \% \mathrm{CO}_{2}$ environment. After this time, cells were fixed with paraformaldehyde and stained with crystal violet. Cells were wiped away from the top of transwell filters before counting cells on the bottom (i.e., those cells that have migrated across the filter). Cells were counted immediately after staining or were stored at $4^{\circ} \mathrm{C}$ in PBS. We used a Leica DMRB microscope (Vashau Scientific, Atlanta, GA) to count cells. An investigator blinded to the identity of the transwell filter counted cells from four random fields. A digital CCD camera connected to an IBM-compatible PC (Dell Computers) was used to capture images of the bottom of transwell filters. Drugs were added to both sides of the filter $1 \mathrm{hr}$ after plating cells. The bottoms of filters were coated with extracellular matrix (ECM) by a $24 \mathrm{hr}$ incubation in PBS with $10 \mu \mathrm{g} / \mathrm{ml}$ laminin or vitronectin in PBS (Sigma) or mock-coated with $0.1 \%$ bovine serum albumin.

Analysis. Data were analyzed off-line with the software package Origin (v.5.0; Microcal Software, Northhampton, MA). All curve-fitting was performed using a least-squares curve-fitting routine provided by the software. Inhibition curves were fit with the following equation:

$$
I / I_{\max }=1 /\left(1+\left([\operatorname{drug}] / \mathrm{IC}_{50}\right)^{\mathrm{n}}\right)
$$

where $I / I_{\max }$ is the fractional remaining current, $\mathrm{IC}_{50}$ is the half-maximal inhibitory concentration, and $n$ is the Hill slope. We calculated input resistance $\left(R_{\mathrm{in}}\right)$ with voltage steps from -40 to $-60 \mathrm{mV}$, as follows:

$$
R_{\text {in }}=[-60 \mathrm{mV}-(-40 \mathrm{mV})] / I_{-40 \rightarrow-60 \mathrm{mv}}
$$

$I_{-40} \rightarrow-60 \mathrm{mv}$ is the steady-state current change that is produced by a voltage step from -40 to $-60 \mathrm{mV}$. The relative permeability of iodide to chloride for whole-cell currents under isotonic and hypotonic conditions $\left(P_{\mathrm{I}} / P_{\mathrm{Cl}}\right)$ was calculated from shifts in reversal potential $\left(\Delta E_{\mathrm{rev}}\right)$ with the constant field equation (Hille, 1992), as follows:

$$
P_{\mathrm{I}} / P_{\mathrm{Cl}}=\left[\left[\mathrm{Cl}^{-}\right]_{\mathrm{o}}\left(\mathrm{e}^{\left[\Delta E_{\mathrm{rev}}(\mathrm{ZF} / \mathrm{RT})\right]}\right)\right] /\left[\mathrm{I}^{-}\right]_{\mathrm{o}} .
$$

$\Delta E_{\mathrm{rev}}$ is the shift in reversal potential seen from switching the bathing solution from the initial extracellular $\mathrm{Cl}^{-}$concentration, $\left[\mathrm{Cl}^{-}\right]_{\mathrm{o}}$, to a solution with an extracellular $\mathrm{I}^{-}$concentration, $\left[\mathrm{I}^{-}\right]_{\mathrm{o}}$. $\mathrm{zF} / \mathrm{RT}$ was -0.017 under our conditions.

Statistical analysis was performed with Excel (Microsoft, Bellevue, WA). We used a two-tailed $t$ test to evaluate data for statistical significance with an $\alpha$ value of $p<0.05$ ( $p$ values are given in Results).

\section{RESULTS}

\section{Volume-activated $\mathbf{C l}$ currents}

We hypothesize that $\mathrm{Cl}^{-}$currents are activated during the migration of human glioma cells, periods during which these cells undergo shape and/or volume changes. Volume-activated $\mathrm{Cl}^{-}$ currents $\left(I_{\mathrm{Cl}, \mathrm{Vol}}\right)$, those currents activated by cell-swelling with hypotonic solutions, are likely candidates to fulfill this role. We began our study by examining the properties of the volumeactivated $\mathrm{Cl}^{-}$currents in human glioma cells. We performed experiments on two well characterized glioma cell lines, D54MG (glioblastoma multiforme) and STTG1 (anaplastic astrocytoma). Glioma cells exposed to hypotonic solutions rapidly (within 10-20 sec) activated currents that reversed near the equilibrium potential for $\mathrm{Cl}^{-}$ions $\left(E_{\mathrm{Cl}}\right.$ was $+2 \mathrm{mV}$ under hypotonic conditions) (Fig. $1 A, B)$. The activation of these currents by hypotonic solutions was accompanied by visible cell-swelling that was reversible on return to control solutions. Hypotonicity-induced currents were readily activated by a change in osmolarity from 300 to $260 \mathrm{mOsm}$ and gave a graded response to the hypotonic challenge. The peak current densities (at $-40 \mathrm{mV}$ ) were $-0.32 \pm$ $0.6,-22 \pm 10$, and $-62 \pm 21 \mathrm{pA} / \mathrm{pF}$ with $\approx 300 \mathrm{mOsm}$ (control conditions), $\approx 260 \mathrm{mOsm}$, and $\approx 200 \mathrm{mOsm}$, respectively (mean \pm $\mathrm{SD}, n=3-12$ cells). Currents activated by hypotonic challenge were $>80 \%$ inhibited by external application of several well known antagonists of $I_{\mathrm{Cl} \text {, Vol }}$, including NPPB (165 $\left.\mu \mathrm{M}\right)$, tamoxifen $(10 \mu \mathrm{M})$, DIDS $(100 \mu \mathrm{M})$, and $\mathrm{Zn}^{2+}(1 \mathrm{mM})$. Examples of reversible block of hypotonicity-induced currents by NPPB and tamoxifen are shown in Figure 1. NPPB effects reversed faster than those of tamoxifen. For this reason, we preferred the use of NPPB to achieve potent, voltage-independent block of these currents. At the end of a hypotonic challenge, a sharp increase in outward current was transiently seen, consistent with these currents being $\mathrm{Cl}^{-}$currents (from hypotonic solution to control, $\left[\mathrm{Cl}^{-}\right]_{\mathrm{o}}$ goes from 83 to $138 \mathrm{~mm}$ ) (Fig. $1 A, C$ ). In addition, increasing $\left[\mathrm{Cl}^{-}\right]_{\mathrm{o}}$ during the return to isotonic bath negatively shifted the reversal potential of these currents (Fig. 1D). The magnitude of these shifts compared well to those predicted for a pure $\mathrm{Cl}^{-}$ current (Fig. 1E). The volume sensitivity, pharmacology, and $\left[\mathrm{Cl}^{-}\right]_{\mathrm{o}}$ dependence of these currents strongly suggest they represent $I_{\mathrm{Cl} \text {,Vol }}$, similar to $I_{\mathrm{Cl} \text {,Vol }}$ described in other human preparations, including different glioma cell lines (Rasola et al., 1992; Bakhramov et al., 1995).

Volume-activated $\mathrm{Cl}^{-}$currents have been shown to be regulated by tyrosine kinases (Sorota, 1995; Crepel et al., 1998), 

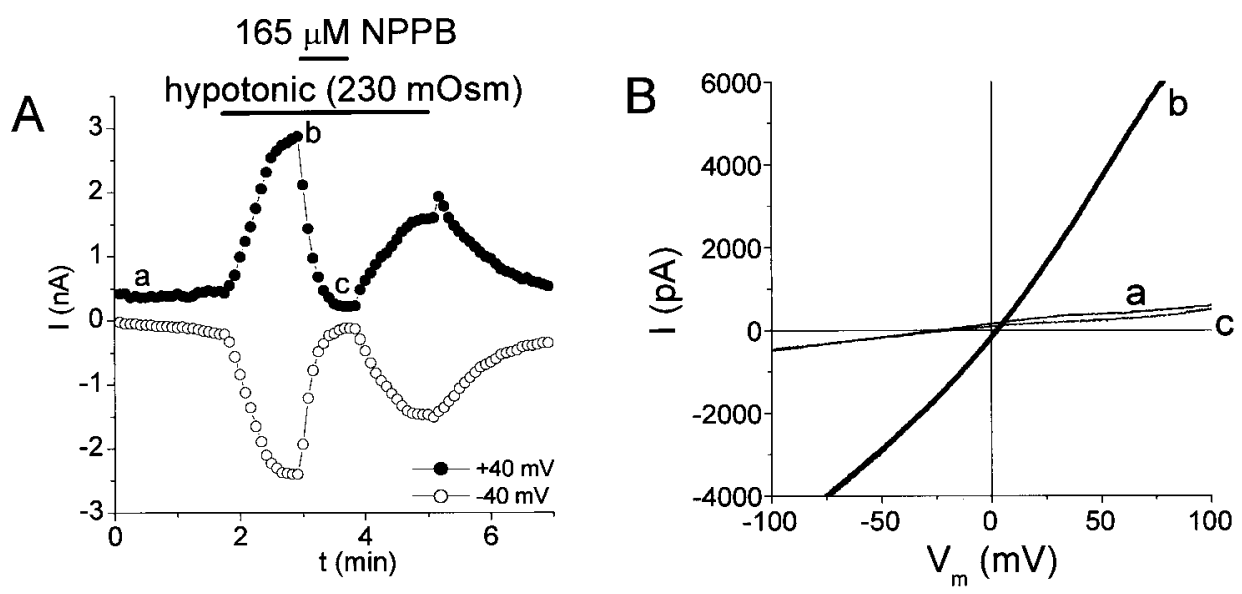

Figure 1. Glioma cells rapidly activate $\mathrm{Cl}^{-}$currents after exposure to hypotonic solutions. $A$, Time course of current activation by hypotonic solutions and block by NPPB $(165 \mu \mathrm{M})$. Horizontal bars indicate period of solution change in this and subsequent figures. $B$, Current responses to voltage ramps (from the experiment in $A$ at time points indicated with $a-c$ ). $C$, Time course of current activation by hypotonic solutions and block by tamoxifen $(10 \mu \mathrm{M}) . D$, Current responses to voltage ramps before and after return to isotonic solution (a change in $\left[\mathrm{Cl}^{-}\right]_{\mathrm{o}}$ from 83 to $138 \mathrm{~mm}$ ). The reversal potential shifts negatively when $\left[\mathrm{Cl}^{-}\right]_{\mathrm{o}}$ is increased, consistent with a $\mathrm{Cl}^{-}$current. Letters in time courses correspond to the traces in D. E, Summary of shifts in reversal potential at the end of hypotonic exposure. These shifts compare well with those predicted by the Nernst equation for a pure $\mathrm{Cl}^{-}$current.
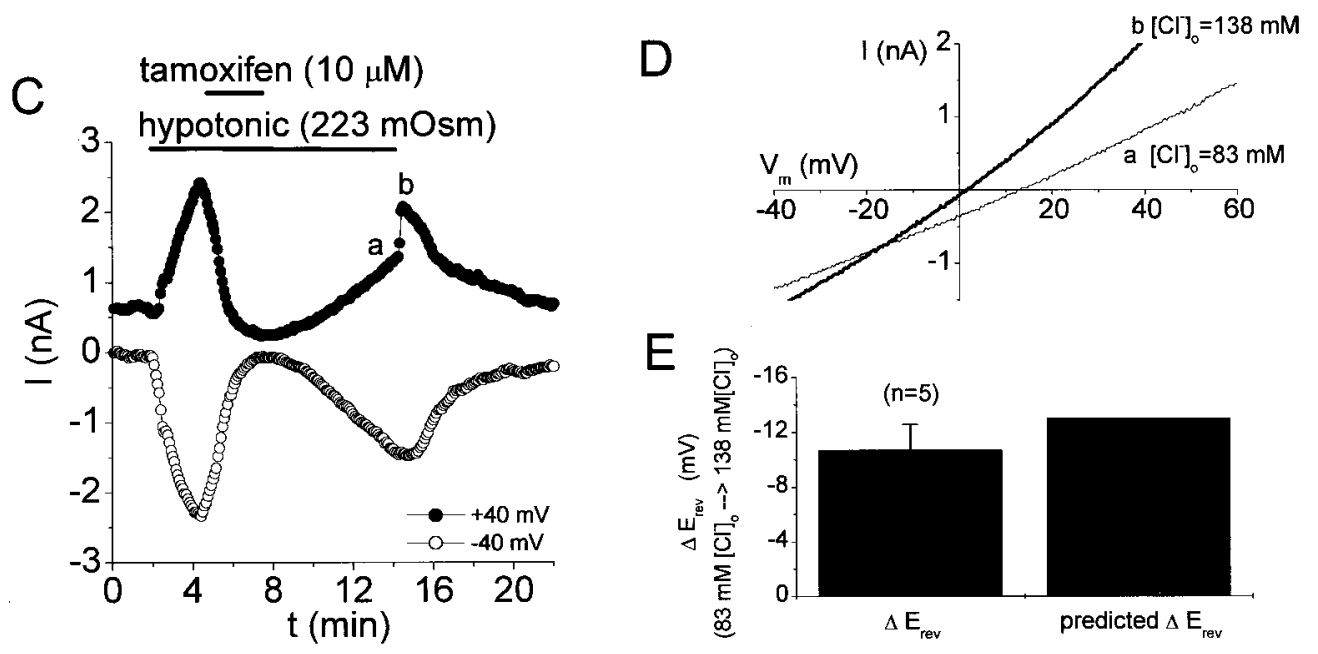

serine-threonine kinases (Duan et al., 1999), protein phosphatases (Duan et al., 1999), and $\mathrm{Ca}^{2+}$-dependent depolymerization of actin (Lascola and Kraig, 1998; Lascola et al., 1998). We examined the biochemical mechanisms underlying hypotonicityinduced activation of $I_{\mathrm{Cl}, \mathrm{Vol}}$ in D54MG glioma cells by including drugs in our pipette solution and allowing a 5 min delivery period after obtaining a whole-cell recording that was followed by a 5 min exposure to solution with an osmolarity of $\approx 200$ mOsm. Drugs were added to the pipette solution at concentrations 10- to 15-fold higher than the $\mathrm{IC}_{50}$ to improve diff usional delivery to the cytoplasm. Inclusion of ATP (2 mM) and GTP (1 mM) in our pipette solutions did not significantly modify the peak current density or rate of activation of $I_{\mathrm{Cl} \text {,Vol }}$ during application of hypotonic bath solution. Peak current density at $-40 \mathrm{mV}$ was $-59 \pm$ 10 and $-64 \pm 28 \mathrm{pA} / \mathrm{pF}$ with intracellular ATP/GTP $(n=3)$ and for same-coverslip control cells $(n=8)$, respectively. We performed experiments with genistein (to inhibit tyrosine kinases; 25 $\mu \mathrm{M}$ ), staurosporine (to inhibit serine-threonine kinases; $120 \mathrm{nM}$ ), and phalloidin (to prevent depolymerization of actin; $1.3 \mu \mathrm{M}$ ). We also performed experiments with 0 extracellular $\mathrm{Ca}^{2+}$ and 10 mM intracellular BAPTA to prevent intracellular $\mathrm{Ca}^{2+}$ rises during hypotonic exposure. None of these manipulations prevented $I_{\mathrm{Cl} \text {,Vol }}$ activation or significantly altered the peak current density of $I_{\mathrm{Cl}, \mathrm{Vol}}$ compared with same-coverslip controls. The mean values for peak current density $(\mathrm{pA} / \mathrm{pF}$ at $-40 \mathrm{mV})$ were $-41 \pm 13(n=7),-54 \pm 13(n=3 ; p=0.21),-32 \pm 25(n=$ $4 ; p=0.55)$, and $-34 \pm 25(n=7 ; p=0.57)$ for control conditions, genistein, staurosporine, and phalloidin, respectively.
The peak current density with 0 added extracellular $\mathrm{Ca}^{2+}$ and 10 $\mathrm{mM}$ intracellular BAPTA was $-41 \pm 14 \mathrm{pA} / \mathrm{pF}(n=3 ; p=0.99)$. The inability to block $I_{\mathrm{Cl} \text {,Vol }}$ activation pharmacologically is suggestive of mechanical activation of $\mathrm{Cl}^{-}$channels after cellswelling with hypotonic solution. Intriguingly, mechanosensitive $\mathrm{Cl}^{-}$channels blocked by NPPB have been reported in neuronal growth cones (Imai et al., 2000).

\section{$\mathrm{Cl}^{-}$currents under isotonic conditions}

Our pharmacologic experiments on $I_{\mathrm{Cl}, \mathrm{Vol}}$ showed that the current remaining in the presence of $165 \mu \mathrm{M}$ NPPB or $10 \mu \mathrm{M}$ tamoxifen was smaller than the control current before cell swelling (Fig. 1C), suggesting that glioma cells have a resting $\mathrm{Cl}^{-}$ conductance under isotonic conditions. We studied this resting $\mathrm{Cl}^{-}$conductance with two approaches; we substituted extracellular $\mathrm{Cl}^{-}$with poorly permeant anions (glutamate ${ }^{-}$and gluconate ${ }^{-}$) and pharmacologically inhibited the resting $\mathrm{Cl}^{-}$conductance (Fig. 2). Figure $2 A$ shows a representative experiment in which $\mathrm{Cl}^{-}$was substituted with glutamate ${ }^{-}$under isotonic conditions. $\mathrm{Cl}^{-}$-substitution with poorly permeant (glutamate or gluconate ${ }^{-}$) anions resulted in a reduction of outward currents and a positive shift in reversal potential. Both of these results are consistent with a resting $\mathrm{Cl}^{-}$conductance under isotonic conditions. In addition, $I_{\mathrm{Cl}, \mathrm{Vol}}$ antagonists significantly increased the input resistance $\left(R_{\mathrm{in}}\right)$ of glioma cells under isotonic conditions (Fig. 2B). Figure $2 C$ summarizes the effects of the $I_{\mathrm{Cl} \text {, Vol }}$ antagonists NPPB and tamoxifen on $R_{\text {in }}$ of glioma cells under isotonic conditions. On average, NPPB increased input resistance by $90 \%$. 

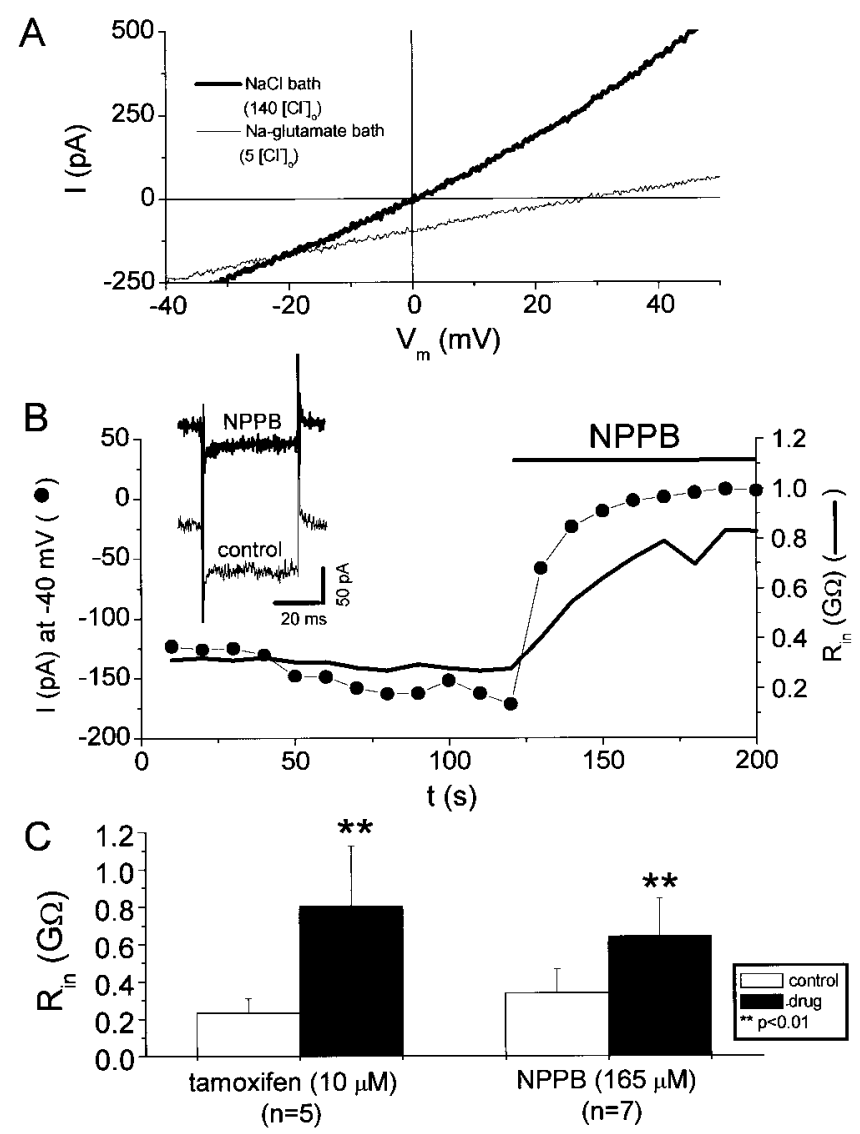

Figure 2. Glioma cells have a resting chloride conductance under isotonic conditions. $A$, Current responses to voltage ramps in a D54MG cell with control bath solution $\left(135 \mathrm{~mm}\left[\mathrm{Cl}^{-}\right]_{\mathrm{o}}\right)$ and Na-glutamate bath solution $\left(5 \mathrm{~mm}\left[\mathrm{Cl}^{-}\right]_{\mathrm{o}}\right) \cdot\left[\mathrm{Cl}^{-}\right]_{\mathrm{o}}$ substitution with poorly permeant anions positively shifted the reversal potential of whole-cell currents. $\left[\mathrm{Cl}^{-}\right]_{0}$ substitution primarily affected the outward currents, as expected if $\mathrm{Cl}^{-}$ was contributing to these currents. Pipette and bath solutions were isotonic. $B$, The $I_{\mathrm{Cl}, \mathrm{Vol}}$ inhibitor NPPB inhibited resting inward currents and increased the input resistance of cells under isotonic conditions. Inset shows current responses before and after application of NPPB $(0.16 \mathrm{~mm})$ to voltage steps from -40 to $-60 \mathrm{mV}$. $C$, Summary of the effects of the $I_{\mathrm{Cl}, \mathrm{Vol}}$ inhibitors tamoxifen and NPPB on the input resistance $\left(R_{\mathrm{in}}\right)$ of D54MG cells under isotonic conditions.

Time- and voltage-dependent inactivation at positive voltages is another feature of volume-activated $\mathrm{Cl}^{-}$currents described for many cell types, including astrocytes (Lascola et al., 1998), endothelial cells (Von Weikersthal et al., 1999), Caco-2 cells (Trouet et al., 1999), colonic carcinoma cells (Worrell et al., 1989), and other human glioma cells (Bakhramov et al., 1995). We also observed this voltage-dependent activation for hypotonicity-induced currents (data not shown). $\mathrm{Cl}^{-}$currents pharmacologically isolated under isotonic conditions (tetraethylammonium ion to block BK currents) (Ransom and Sontheimer, 2001) or with $\mathrm{CsCl}$ pipette solutions showed all the hallmarks of $I_{\mathrm{Cl} \text {,Vol}}$. These include reversal near $E_{\mathrm{Cl}}$, time- and voltagedependent inactivation, and slight outward rectification (Fig. 3). We were able to infer that the inactivating currents represent those active at rest because voltage steps that caused inactivation $(>+60 \mathrm{mV})$ resulted in a decrease in the holding current (at -40 $\mathrm{mV}$ ). The degree of inactivation of currents evoked with voltage steps was in excellent quantitative agreement with the inactivation of holding currents (at $-40 \mathrm{mV}$ ). For the records in Figure $3 C$, the ratio of the current at the end of the voltage step to the
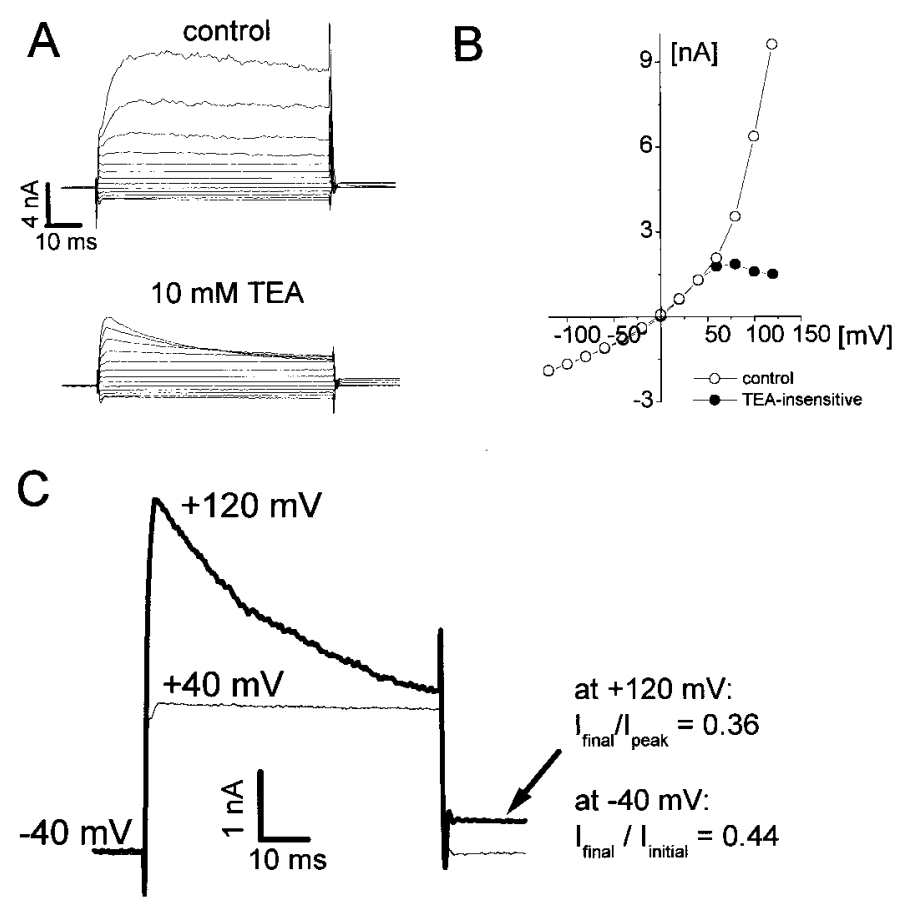

Figure 3. Kinetics of $\mathrm{Cl}^{-}$currents under isotonic conditions. A, Wholecell currents evoked with voltage steps from -120 to $+160 \mathrm{mV}$ from a holding potential of $-40 \mathrm{mV}$ before and after application of tetraethylammonium ion (TEA, $10 \mathrm{mM}$ ). $\mathrm{KCl}$ pipette solution. $B, I-V$ plot of the steady-state currents under control conditions and with TEA. TEA blocks the BK currents present in these cells (Ransom and Sontheimer, 2001). C, TEA-insensitive currents evoked with voltage steps to +40 and $+120 \mathrm{mV}$ $\left(V_{\mathrm{h}}\right.$ of $\left.-40 \mathrm{mV}\right)$. At potentials greater than $+100 \mathrm{mV}$, TEA-insensitive currents displayed inactivation. This voltage-dependent inactivation resulted in a reduction in the holding current $(-40 \mathrm{mV}$; arrow $)$. The degree of inactivation of currents evoked with voltage steps was in excellent quantitative agreement with that seen for holding currents $(-40 \mathrm{mV})$.

peak current was 0.36 , and the ratio of holding current after to the holding current before the voltage step was 0.44 . We did not examine the time course of recovery from inactivation in detail but the reduction in holding current after voltage-dependent inactivation of $\mathrm{Cl}^{-}$channels completely recovered within $10 \mathrm{sec}$.

Volume-activated $\mathrm{Cl}^{-}$channels have been shown to be regulated by intracellular ATP, $\mathrm{Ca}^{2+}$, tyrosine kinases, serinethreonine kinases, protein phosphatases, and cytoskeletal actin (Sorota, 1995; Crepel et al., 1998; Lascola et al., 1998; Duan et al., 1999). An important issue regarding the resting $\mathrm{Cl}^{-}$conductance is whether cell dialysis during whole-cell recordings subtly alters cell volume or channel regulation, leading to some basal activation. We addressed these concerns by obtaining amphotericin perforated patches from our glioma cells and extracellularly applying the $I_{\mathrm{Cl} \text {,Vol }}$ antagonist NPPB (Fig. 4). As seen with conventional whole-cell recordings, NPPB increased the input resistance in nondialyzed cells. In perforated-patch-clamped cells, $R_{\text {in }}$ was $155 \pm 92$ and $256 \pm 102 \mathrm{M} \Omega(65 \%$ increase $)$ under control conditions and with $165 \mu \mathrm{M} \mathrm{NPPB}$, respectively $(p<0.05 ; n=$ 10). Most importantly, NPPB always blocked an inward current in perforated-patch-clamped cells at typical resting potentials $(-40$ $\mathrm{mV}$ ) (Fig. 4C). This last result indicates that glioma cells actively regulate $\left[\mathrm{Cl}^{-}\right]_{\mathrm{i}}$ such that $E_{\mathrm{Cl}}$ is positive to the resting potential leading to $\mathrm{Cl}^{-}$efflux at the resting potential. The larger input resistances in our whole-cell recordings compared with perforatedpatch recordings are likely caused by inhibition of $\mathrm{K}^{+}$currents by 
A

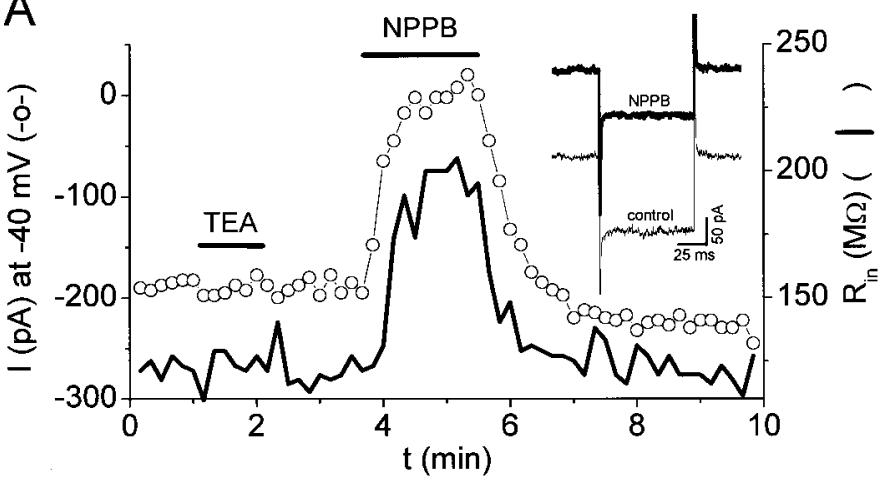

$\mathrm{B}$
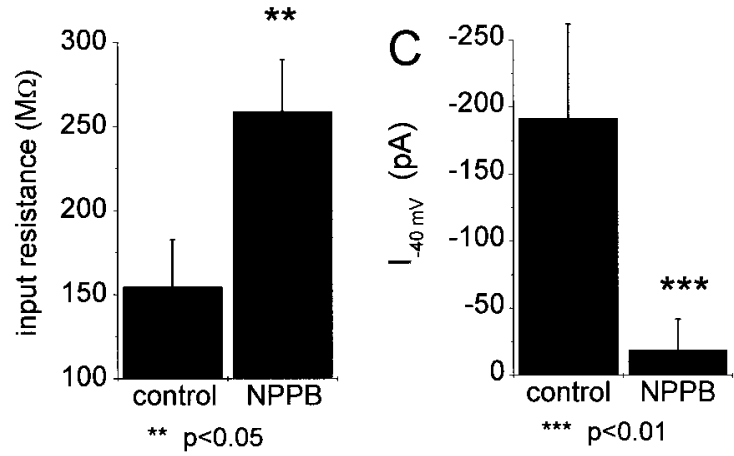

Figure 4. The resting chloride conductance of glioma cells is present in nondialyzed cells (amphotericin perforated-patch clamp). A, Double $y$-axis plot of current (at $-40 \mathrm{mV})$ and input resistance $\left(R_{\mathrm{in}}\right)$ as a function of time in an amphotericin perforated-patch-clamped cell. NPPB (165 $\mu \mathrm{M})$, but not TEA (1 $\mathrm{mM})$, blocked an inward current at typical resting potentials $(-40 \mathrm{mV})$ and increased the input resistance. Inset shows current responses to a voltage step from -40 to $-60 \mathrm{mV}$ before and after NPPB application (used to calculate input resistance). The series resistance of this cell was $22 \mathrm{M} \Omega$. B, Summary of NPPB effects on input resistance in cells recorded from in the perforated-patch configuration. $C$, Summary of NPPB effects on current at $-40 \mathrm{mV}$ in cells recorded from in the perforated-patch configuration. Data in $B$ and $C$ are displayed as mean $\pm \mathrm{SE}$.

the $\mathrm{CsCl}$ pipette solutions. In perforated-patch experiments, we observed no effect of $1 \mathrm{~mm}$ TEA on currents at $-40 \mathrm{mV}$ or on input resistance. TEA and NPPB are therefore acting on distinct ionic conductances.

Results presented thus far suggest that (1) glioma cells are endowed with $I_{\mathrm{Cl} \text {,Vol }}$ and (2) $I_{\mathrm{Cl}, \mathrm{Vol}}$ is constitutively active under isotonic conditions. We examined one other hallmark of $I_{\mathrm{Cl}, \mathrm{Vol}}$, namely an $\mathrm{I}^{-}>\mathrm{Cl}^{-}$selectivity (Rasola et al., 1992; Diaz et al., 1993; Pollard, 1993; Duan et al., 1997; Bond et al., 1998a; Von Weikersthal et al., 1999), to evaluate whether the currents active at rest represent the same currents activated with hypotonicity.

\section{Relative iodide permeability of $I_{\mathrm{Cl}, \mathrm{Vol}}$ and resting Cl currents}

If $I_{\mathrm{Cl}, \mathrm{Vol}}$ underlies the resting $\mathrm{Cl}^{-}$conductance in glioma cells, the whole-cell currents under isotonic and hypotonic conditions should have the same selectivity sequence. We examined the relative permeability of $\mathrm{I}^{-}$to $\mathrm{Cl}^{-}$for both the resting $\mathrm{Cl}^{-}$ conductance and hypotonicity-induced currents (Rasola et al., 1992; Diaz et al., 1993; Pollard, 1993; Duan et al., 1997; Bond et al., 1998a; Von Weikersthal et al., 1999). Replacement of $\mathrm{NaCl}$ with $\mathrm{NaI}$ under isotonic conditions increased outward current amplitude and negatively shifted the reversal potential of wholecell currents (Table 1). Activation of currents with hypotonic solution followed by application of hypotonic solution with $\mathrm{NaI}$ replacing $\mathrm{NaCl}$ similarly increased outward currents and negatively shifted reversal potentials. Calculation of the relative permeability of $\mathrm{I}^{-}$to $\mathrm{Cl}^{-}\left(P_{\mathrm{I}} / P_{\mathrm{Cl}}\right)$ with the Goldman-HodgkinKatz equation suggested a $P_{\mathrm{I}} / P_{\mathrm{C} 1}$ of 1.6 for whole-cell currents under isotonic and hypotonic conditions. The liquid junction potential produced by a change from $140\left[\mathrm{Cl}^{-}\right]_{\mathrm{o}}$ to $135\left[\mathrm{I}^{-}\right]_{\mathrm{o}}$ was determined to be approximately $-1 \mathrm{mV}$. The values in Table 1 were not corrected for this.

\section{Inhibition of glioma cell migration by NPPB}

We evaluated the participation of chloride currents in glioma cell migration by performing transwell migration assays, an in vitro model for invasive migration (see Materials and Methods). These assays involve plating cells on the top of a culture plate insert with a filter consisting of $8 \mu \mathrm{m}$ pores, providing three-dimensional constraints on migrating cells. Cells must change their shape to navigate these pores and cross to the bottom of the filter. In the absence of ECM (mock coating of filter with bovine serum albumin), essentially no directional cell movement across the transwell filter was observed (Fig. $5 A$ ). Coating the bottom of the filter with ECM potently increased directional, chemotactic migration of glioma cells to the bottom of the transwell filter. This enhanced migration in the presence of ECM was abrogated by NPPB. For the experiment in Figure 5, $30 \mu \mathrm{M}$ NPPB reduced transwell migration by $62 \%$. If NPPB is reducing migration by inhibiting volume-activated $\mathrm{Cl}^{-}$currents, NPPB inhibition of migration and of volume-activated $\mathrm{Cl}^{-}$currents is predicted to have a similar concentration dependence. We determined doseresponse relationships for NPPB inhibition of volume-activated $\mathrm{Cl}^{-}$currents and for transwell migration assays (Fig. 6). Plotting normalized volume-activated $\mathrm{Cl}^{-}$current as a function of NPPB concentration and fitting these data with a Langmuir binding isotherm (Materials and Methods) suggested an $\mathrm{IC}_{50}$ of $21 \mu \mathrm{M}$ (Fig. 6B). The concentration dependence of NPPB inhibition of transwell migration was in excellent agreement with patch-clamp data for volume-activated $\mathrm{Cl}^{-}$currents. The solid line in Figure $6 B$ is the fit to patch-clamp data. We also fit transwell migration data with the same equation and obtained an $\mathrm{IC}_{50}$ of $27 \mu \mathrm{M}$. These results support the hypothesis that volume-activated $\mathrm{Cl}^{-}$ currents are activated during, and contribute to, the migration of human glioma cells. Data in Figures 5 and 6 are from D54MG cells, but we obtained similar results with two other glioma cell lines (U373MG and STTG1). Our data agrees with previous studies showing that tamoxifen inhibited glioma cell migration (Soroceanu et al., 1999). NPPB effects could be reversed after 4 hr of exposure by exchanging the solutions on top and bottom of the transwell filter insert (data not shown).

\section{Spontaneous activation of $I_{\mathrm{CI}, \mathrm{Vol}}$}

In the absence of hypotonic stimulation, the majority of cells did not display significant changes in input resistance during the recording period (up to $30 \mathrm{~min}$ ). However, there were examples of spontaneously developing currents during whole-cell recordings. These spontaneously activating currents were roughly linear and sensitive to NPPB. To determine whether these spontaneously activating currents were associated with changes in cell shape or size, we made time-lapse video recordings of cells during whole-cell recording. We obtained examples of clear, unidirectional movement in glioma cells, and this movement was invariably associated with an increase in whole-cell currents across a range of potentials (Fig. 7). The cell shown in Figure $7 A-D$ began 


\begin{tabular}{llllll}
\hline \multicolumn{5}{l}{ Table 1. Shifts in reversal potential produced by iodide under isotonic and hypotonic conditions } \\
& $E_{\mathrm{rev}}[\mathrm{Cl}]_{\mathrm{o}}$ & $E_{\mathrm{rev}}[\mathrm{I}]_{\mathrm{o}}$ & $\Delta E_{\mathrm{rev}}$ & $P_{\mathrm{I}^{-}} / P_{\mathrm{Cl}^{-}}$ & $n$ \\
\hline Isotonic & $-16 \pm 15 \mathrm{mV}$ & $-26 \pm 16 \mathrm{mV}$ & $-11 \pm 3 \mathrm{mV}$ & $1.6 \pm 0.2$ & 14 \\
& $(-66$ to $-12 \mathrm{mV})$ & $(-51$ to $-1 \mathrm{mV})$ & & & \\
Hypotonic & $-2 \pm 5 \mathrm{mV}$ & $-12 \pm 7 \mathrm{mV}$ & $-11 \pm 4 \mathrm{mV}$ & $1.6 \pm 0.3$ & 15 \\
& $(-11$ to $+6 \mathrm{mV})$ & $(-29$ to $-4 \mathrm{mV})$ & & &
\end{tabular}

Values are mean \pm SD. Numbers in parentheses are ranges. For isotonic conditions, $[\mathrm{Cl}]_{\mathrm{o}}=140 \mathrm{~mm}$, and $[\mathrm{I}]_{\mathrm{o}}=135 \mathrm{~mm}$. For hypotonic conditions, $[\mathrm{Cl}]_{\mathrm{o}}=85 \mathrm{~mm}$, and $[\mathrm{I}]_{\mathrm{o}}=80 \mathrm{~mm}$. Hypotonic solutions were $\approx 215 \mathrm{mOsm}$. CsCl pipette solution.

to extend a leading process after $\approx 3$ min of whole-cell recording (acquisition was begun $\approx 2$ min after obtaining a whole-cell recording). Over the next several minutes, this process (Fig. $7 A-D$, white arrow) continued to extend and broaden. Contraction of the trailing process in the upper left-hand corner can be appreciated in the final frame (Fig. 7D). Currents progressively increased during these events (Fig. $7 E$ ). Currents activated during movement could be distinguished from nonspecific leak associated with loss of giga-seal integrity by their sensitivity to NPPB. Movement ceased after application of NPPB to the cell in Figure 7. However, it is impossible for us to know how far these events would have progressed in the absence of NPPB. In addition, we do not predict NPPB to have any effects on cell motility under these conditions because tamoxifen, another $I_{\mathrm{Cl} \text {,Vol }}$ antagonist, has no effect on the two-dimensional migration of glioma cells (Soroceanu et al., 1999). Activation of currents during movement was accompanied by positive shifts in reversal potential, consistent with the pharmacologic identification of these currents as $\mathrm{Cl}^{-}$currents. We observed spontaneous activation of $\mathrm{Cl}^{-}$currents ( $>25 \%$ change in input resistance) in 4 of 15 cells from which we obtained simultaneous whole-cell recordings and time lapse video images. Spontaneous activation was invariably associated with changes in cell shape and movement. One concern regarding these experiments is whether the patch pipette itself could have introduced membrane stress or modified the cytoskeleton, thereby leading to channel activation. Given the low frequency of spontaneous activation of $\mathrm{Cl}^{-}$currents $(<30 \%)$, we do not believe this to be the case. These experiments were performed with $\mathrm{KCl}$ pipette solutions in the absence of TEA.

\section{DISCUSSION}

Our experiments demonstrate that chloride channels mediate a substantial portion of the resting conductance of D54MG and STTG-1 glioma cells. Drugs that inhibit these $\mathrm{Cl}^{-}$channels abrogated migration of glioma cells in vitro. Resting $\mathrm{Cl}^{-}$currents were present in nondialyzed cells (amphotericin perforated patches) indicating that these were not a result of cellular perturbations during whole-cell recordings. The channels that mediate the resting conductance in glioma cells have not been identified. However, we believe that they resemble volume-activated $\mathrm{Cl}^{-}$ channels for the following reasons: (1) resting currents and volume-activated currents shared the same pharmacology, (2) currents under isotonic and hypotonic conditions displayed similar time- and voltage-dependent inactivation, and (3) resting $\mathrm{Cl}^{-}$ channels and volume-activated channels both have an iodide $>$ chloride permeability.

The prominent resting $\mathrm{Cl}^{-}$conductance in human glioma cells is in sharp contrast to the situation in "normal" rodent glia in which a large resting $\mathrm{K}^{+}$conductance predominates (Kettenmann et al., 1983; Ransom and Sontheimer, 1995; Bordey and
Sontheimer, 1997). The latter is mediated by inwardly rectifying $\mathrm{K}^{+}$channels (Newman, 1993; Ransom and Sontheimer, 1995; Kofuji et al., 2000) that were not observed in D54MG glioblastoma cells (see however Brismar and Collins, 1988; Bakhramov et al., 1995). The resting chloride conductance can account for the relatively positive resting membrane potentials of the glioma cells in our study ( -50 to $-10 \mathrm{mV}$ ) (Ullrich and Sontheimer, 1996; Ransom and Sontheimer, 2001). Moreover, similar membrane potentials have been reported for human glioblastoma cells in situ (Picker et al., 1981; Ullrich et al., 1998). Other actively proliferating cells also maintain relatively positive resting membrane potentials (Cone, 1970). Interestingly, neuroblastoma cells and colonic carcinoma cells also have resting $\mathrm{Cl}^{-}$currents (Valverde et al., 1994; Rouzaire-Dubois and Dubois, 1998). This raises the possibility that enhancement of basal $\mathrm{Cl}^{-}$currents is an adaptation of malignant cells that contributes to tumor biology [i.e., uncontrolled proliferation (Shen et al., 2000) and invasive migration (Soroceanu et al., 1999)].

$\mathrm{Cl}^{-}$channels are vitally important for cell volume regulation (O’Connor and Kimelberg, 1993; Pasantes-Morales et al., 1994; Nilius et al., 1995; Jackson and Madsen, 1997; Bond et al., 1998b; Lang et al., 1998; Mignen et al., 1999; Rouzaire-Dubois et al., 1999; Valverde, 1999; Xiong et al., 1999; Wang et al., 2000) (but see Strange, 1988). Ubiquitously expressed volume-activated $\mathrm{Cl}^{-}$ channels are of particular importance for regulatory volume decreases (RVD). During RVD, which cells undergo after swelling, $\mathrm{Cl}^{-}$channels facilitate net salt efflux $\left(\mathrm{Cl}^{-}\right.$and $\mathrm{K}^{+}$ions). Animal cells are endowed with water channels (aquaporins) that keep them in osmotic equilibrium (Jackson and Madsen, 1997; Lang et al., 1998). Therefore, channel-mediated net salt efflux is accompanied by net water efflux leading to cell shrinkage-flattening. Passive, channel-mediated salt efflux ultimately depends on membrane potential and appropriate electrochemical gradients established by membrane transporters. In addition to $\mathrm{Cl}^{-}$ions, $\mathrm{Cl}^{-}$ channels flux organic osmolytes such as taurine (Kirk, 1997). Channel-mediated shape-volume changes also occur under isotonic conditions. For example, in cultured astrocytes, induction of morphological changes is accompanied by chloride channel activation (Lascola and Kraig, 1998). In epithelial cells, activation of $\mathrm{K}^{+}$channels underlies changes in cell volume during cell migration (Danker et al., 1996; Schwab et al., 1999; Schneider et al., 2000).

We hypothesize that in glioma cells, $\mathrm{Cl}^{-}$channels contribute to net salt fluxes underlying the shape-volume changes requisite for glioma cell movement through the tortuous extracellular space of brain (Soroceanu et al., 1999). The invasive migration of glioma cells into surrounding brain tissue complicates surgical treatment (Adams and Victor, 1989), hence, pharmacologic inhibition of glioma $\mathrm{Cl}^{-}$channels may have therapeutic benefits. Of 
A
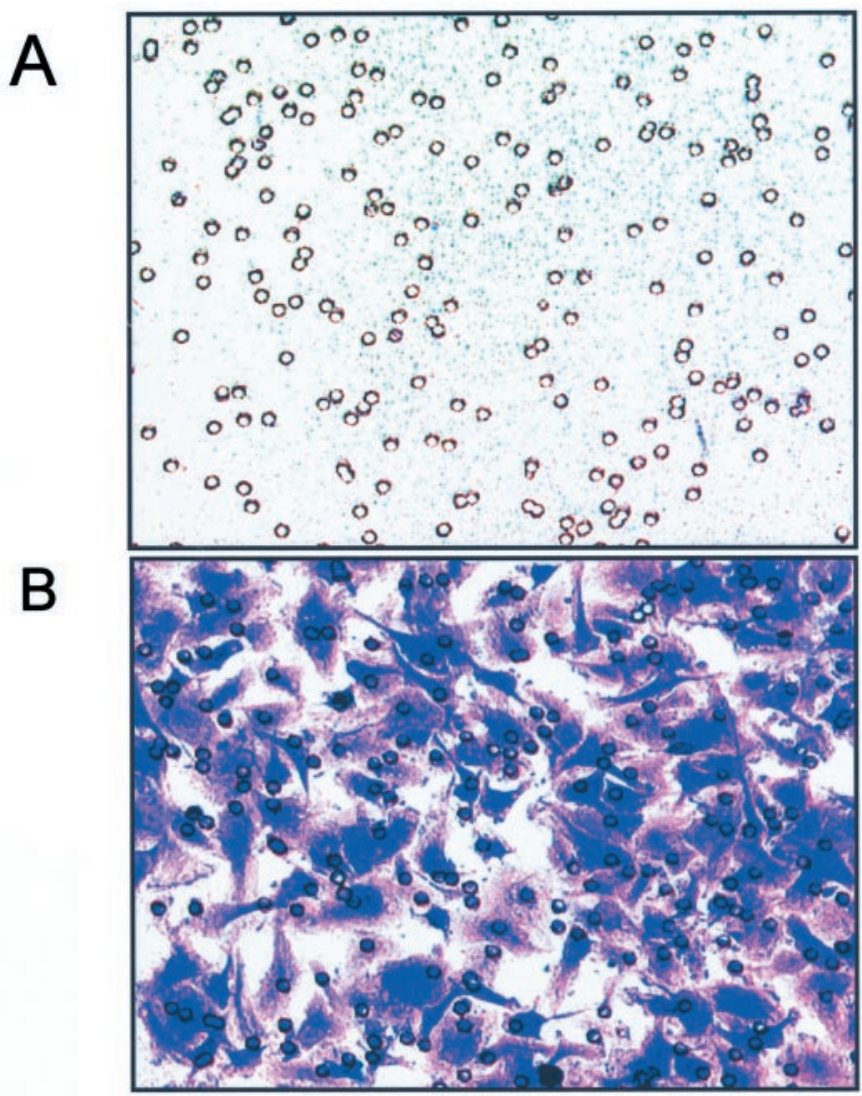

C

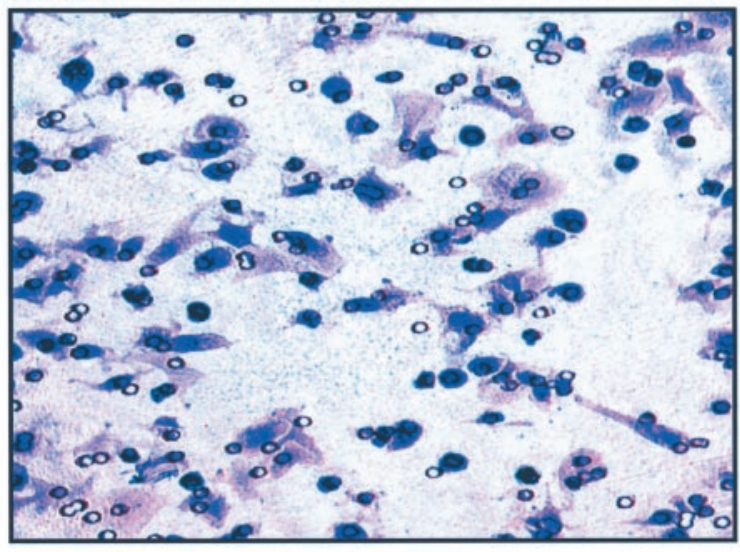

D

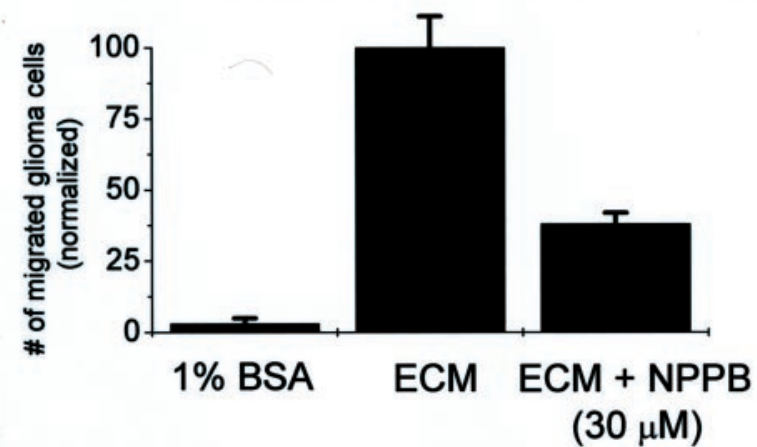

Figure 5. Transwell migration is inhibited by the $I_{\mathrm{Cl} \text {,Vol }}$ antagonist NPPB. $A-C$, Photomicrographs of the bottom of a transwell filter $(8 \mu \mathrm{m}$ pores) coated with bovine serum albumin $(B S A ; 1 \%)(A)$, the extracellular matrix $(E C M)$ molecule vitronectin $(B)$, and vitronectin plus $30 \mu \mathrm{M}$ NPPB $(C)$. Vitronectin stimulates migration that is sensitive to NPPB. $D$, Summary of the experiment illustrated in $A-C$. Data are presented as mean $\pm \mathrm{SE}$ of four transwell filters from a single experiment.
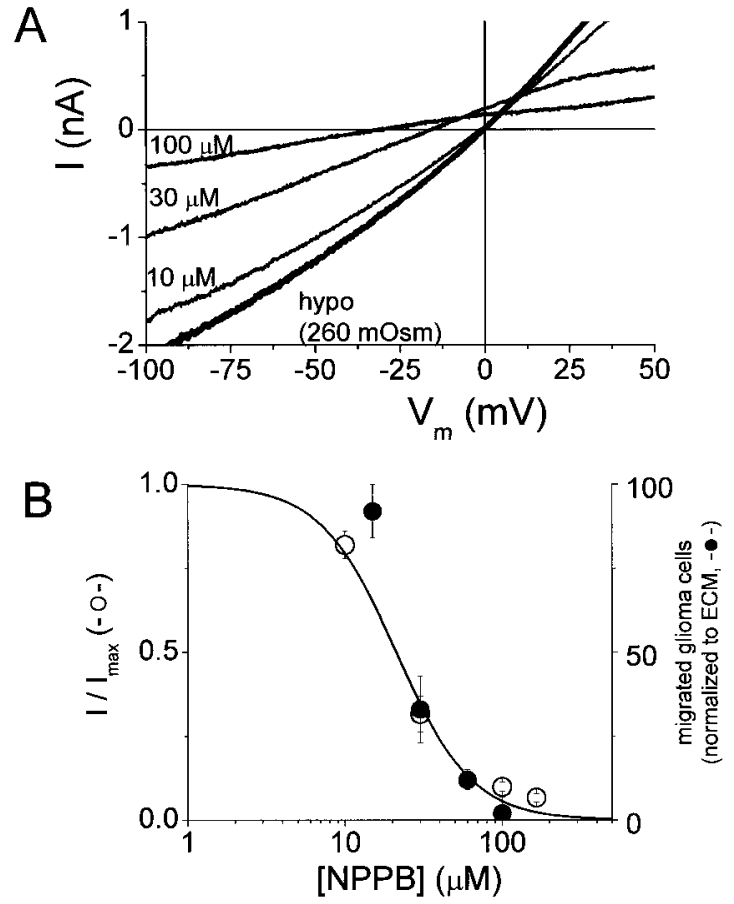

Figure 6. Dose dependence of NPPB inhibition of $I_{\mathrm{Cl}, \mathrm{Vol}}$ and transwell migration. $A$, Representative current traces in response to voltage ramps in a cell exposed to hypotonic solution with increasing NPPB concentrations. Note negative shift in reversal potential as $\mathrm{Cl}^{-}$currents are blocked. $B$, Double $y$-axis plot of NPPB inhibition of $I_{\mathrm{Cl}, \mathrm{Vol}}$ and transwell migration. The solid line is a binding isotherm. The data for NPPB inhibition of transwell migration agreed well with $I_{\mathrm{Cl}, \mathrm{Vol}}$ data. Data points are mean $\pm \mathrm{SE}$ from three to seven experiments.

course, our in vitro migration assays are limited in assessing the complex biology underlying glioma cell invasion. However, these assays do mimic the three-dimensional spatial constraints encountered by invading glioma cells. NPPB inhibited $I_{\mathrm{Cl} \text {,Vol }}$ and transwell migration of glioma cells with almost identical dose dependence $\left(\mathrm{IC}_{50}\right.$ of $21 \mu \mathrm{M}$ and $27 \mu \mathrm{M}$ for $I_{\mathrm{Cl}, \mathrm{Vol}}$ and transwell migration, respectively). These results suggest that the inhibitory effects of NPPB on glioma migration were a consequence of $I_{\mathrm{Cl} \text {,Vol }}$ inhibition and not of nonspecific interactions. NPPB did not lead to cell death because removal of NPPB after $4 \mathrm{hr}$ rescued glioma cell migration in transwell assays. Our results with NPPB are consistent with the reduction of glioma cell migration into fetal rat brain aggregates produced by tamoxifen, which, like $\mathrm{NPPB}$ is a potent blocker of $I_{\mathrm{Cl}, \mathrm{Vol}}$ and the resting $\mathrm{Cl}^{-}$conductance in glioma cells (Soroceanu et al., 1999). These data suggest that inhibition of volume-activated $\mathrm{Cl}^{-}$channels will retard the complex migration of glioma cells in brain as well as in the simplified transwell assays.

Our data also suggest that $I_{\mathrm{Cl}, \mathrm{Vol}}$ is activated during cell movement. We obtained examples of clear unidirectional cell movements that were accompanied by activation of NPPB-sensitive currents (Fig. 7). These currents shifted the reversal potential closer to the Nernst equilibrium potential for chloride $\left(E_{\mathrm{Cl}}\right)$, identifying them as $\mathrm{Cl}^{-}$currents. No spontaneous activation was observed in cells that did not change shape or show cell movements during the recording period. These observations support our hypothesis that chloride currents are activated during cell movement. 

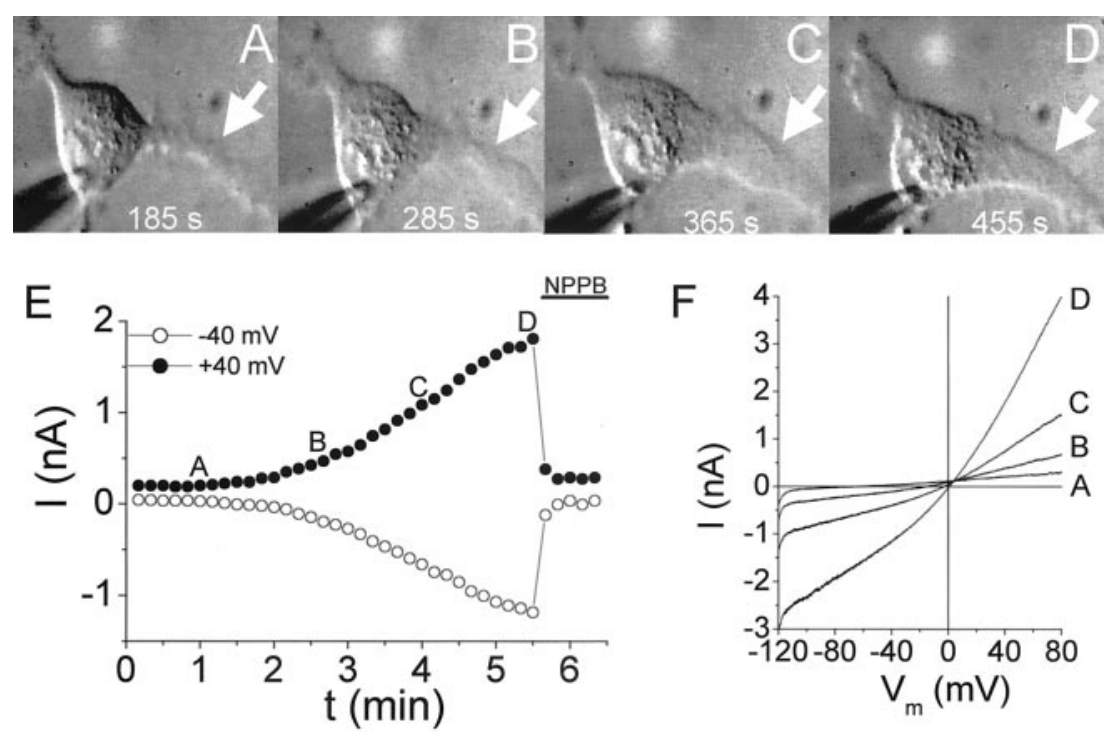

Figure 7. Cell movement is accompanied by spontaneous activation of $I_{\mathrm{Cl}, \mathrm{Vol}}$. $A-D$, Sequential photomicrographs of a D54MG cell. Times indicate when the photomicrographs were taken after obtaining a whole-cell recording. $E$, Time course of current change in this cell. Letters correspond to the photomicrographs in $A-D$. Currents pharmacologically consistent with $I_{\mathrm{Cl}, \mathrm{Vol}}$ (NPPB-sensitive) were activated as the cell began to extend a leading process and contracted its trailing edge. Data acquisition was begun $125 \mathrm{sec}$ after establishing a whole-cell recording. $F$, Ramp currents from the data in $E$. Letters correspond to the time points in $E$.
A

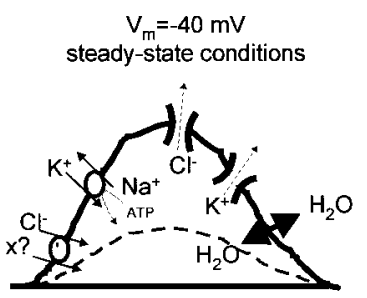

B
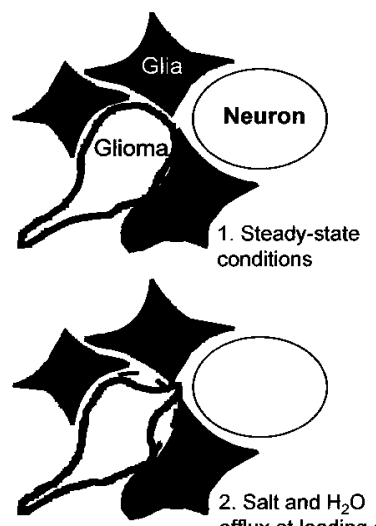

2. Salt and $\mathrm{H}_{2} \mathrm{O}$ shape/volume change

\begin{abstract}
Channel activation: $\rightarrow$ net salt and $\mathrm{H}_{2} \mathrm{O}$ efflux, cell shrinkage/flattening
\end{abstract}
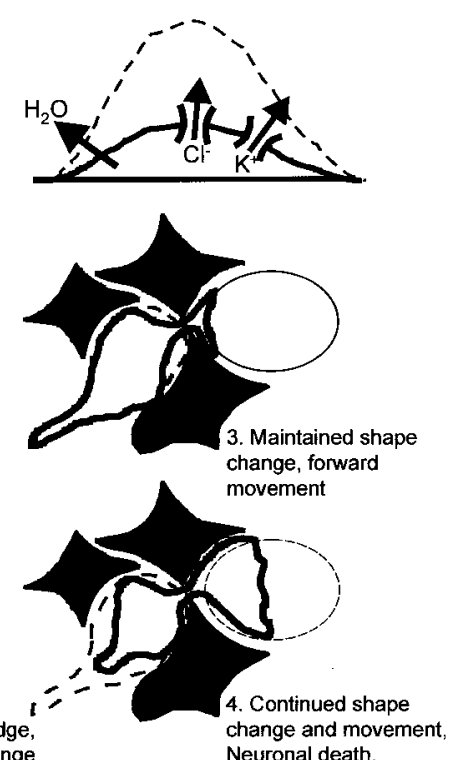
Neuronal death.

Figure 8. Schematic of glioma cell membrane machinery involved in shape-volume change. $A$, Intracellular $\left[\mathrm{Cl}^{-}\right]$is actively regulated to produce $\mathrm{Cl}^{-}$efflux at typical resting membrane potentials by an unknown mechanism [illustrated here as an unidentified transporter $(X)$ ]. Operation of $\left[\mathrm{Cl}^{-}\right]_{\mathrm{i}}$ regulating proteins ultimately depends on electrochemical gradients established by the $\mathrm{Na}^{+} / \mathrm{K}^{+}$-ATPase. Activation of $\mathrm{Cl}^{-}$channels results in $\mathrm{Cl}^{-}$efflux, with accompanying cations and water, leading to cell shrinkage-flattening. $B$, Shrinkage may only occur at the leading edge or invading process and may be transient. Actin-myosin molecular motors provide the forces necessary for cell invasion, with cell volume changes acting primarily in a permissive way.

\section{Model of chloride channel involvement in invasive migration of glioma cells}

In the following section we develop a model for the invasive migration of glioma cells that is consistent with our results (Fig. 8). We propose that invasive migration of glioma cells requires shape and-or volume changes permissive for cell movements through narrow extracellular spaces in brain. Electron microscopic evidence supports the occurrence of such shape changes in migrating glioma cells (Soroceanu et al., 1999). We hypothesize that chloride channel activation leads to $\mathrm{Cl}^{-}$efflux at typical resting potentials that is coupled to cation and water efflux causing cell shrinkage. This requires that glioma cells actively import $\mathrm{Cl}^{-}$ions [depicted as an unidentified $\mathrm{Cl}^{-}$transporter (X) in Fig. $8 A$ ] to keep the equilibrium potential for $\mathrm{Cl}^{-}$positive to the resting potential, thereby providing a driving force for $\mathrm{Cl}^{-}$efflux. The inhibition of inward currents by NPPB during perforatedpatch recordings at typical resting potentials $(-40 \mathrm{mV})$ supports this assumption. The identity of the primary $\left[\mathrm{Cl}^{-}\right]_{\mathrm{i}}$-regulating transporter in glioma cells remains to be shown. Our model also depicts activation of chloride and potassium channels at the leading edge of a migrating glioma cell. The opening of these channels results in cellular salt and water loss and cell shrinkage, permitting a flattening of the leading edge and its extension through narrow extracellular spaces (Fig. 8B). Our data suggest that the $\mathrm{Cl}^{-}$channels activated during glioma migration are NPPB-sensitive volume-activated $\mathrm{Cl}^{-}$channels. We favor mechanical activation of chloride currents during migration, as seen in neuronal growth cones (Imai et al., 2000), because kinase inhibition, prevention of intracellular $\mathrm{Ca}^{2+}$ rises, and actin stabilization did not prevent $I_{\mathrm{Cl}, \mathrm{Vol}}$ activation. The cation flux depicted in our model is most likely accomplished by largeconductance $\mathrm{Ca}^{2+}$-activated $\mathrm{K}^{+}(\mathrm{BK})$ channels that are highly expressed in these cells (Ransom and Sontheimer, 2001). Consistent with this assumption, pharmacological inhibition of BK channels with TEA (1 mM) also inhibits glioma cell transwell migration (Soroceanu et al., 1999). $\mathrm{Ca}^{2+}$-activated $\mathrm{K}^{+}$channels have been implicated in the migration of other cell types (Danker et al., 1996; MacLeod and Hamilton, 1999; Schwab et al., 1999; Schneider et al., 2000), and migrating cells experience intracellular $\mathrm{Ca}^{2+}$ increases required for BK activation (Brundage et al., 1991; Komuro and Rakic, 1996). Possible scenarios for ion channel participation in glioma cell migration would include coactivation of $\mathrm{BK}$ and $I_{\mathrm{Cl}, \mathrm{Vol}}$, perhaps at discrete parts of cells (i.e., leading edge), to induce cell shrinkage. Our results suggest that $\mathrm{Cl}^{-}$channels will be activated above basal levels during migratory events (Fig. 7). However, one consequence of the resting $\mathrm{Cl}^{-}$ conductance in glioma cells is that net salt flux (and subsequent shape-volume change) could be triggered by $\mathrm{K}^{+}$channel activation alone. 
Clearly, cell shrinkage alone is insufficient to permit cell invasion. Importantly, actin-myosin molecular motors propel cells, and in the process cytoskeletal rearrangements must occur to allow shape-volume changes (Maidment, 1997). In glioma cells, as in other cancerous cells, matrix metalloproteinase degradation of extracellular matrix plays an important role in invasion (Belien et al., 1999). In addition, it has been proposed that glioma cells may create room for their growth by killing surrounding neurons through the release of excitotoxic glutamate (Ye and Sontheimer, 1999; Ye et al., 1999). Glutamate release may occur by reversed operation of cystine-glutamate exchange or via the same channels we are proposing to be activated during cell movement (Roy, 1995; Phillis et al., 1998; Basarsky et al., 1999; Ye and Sontheimer, 1999; Ye et al., 1999). Thus, multiple avenues exist by which $\mathrm{Cl}^{-}$channel activity could contribute to glioma cell migration and invasion. Given the complexity of cell migration in brain, we suggest that $\mathrm{Cl}^{-}$channel-mediated shape-volume changes serve a permissive role in the movement of cells along narrow migratory pathways. $\mathrm{Cl}^{-}$channels may function similarly in other motile cells, including fibroblasts, macrophages, microglia, and neural progenitor cells.

In summary, we have found that human glioma cells, in contrast to normal rodent astrocytes, have a resting conductance dominated by $\mathrm{Cl}^{-}$channels. Experiments with amphotericin perforated patches demonstrated that glioma cells distribute $\mathrm{Cl}^{-}$ions to produce $\mathrm{Cl}^{-}$efflux at typical resting membrane potentials. We suggest that resting $\mathrm{Cl}^{-}$currents are mediated by volumeactivated $\mathrm{Cl}^{-}$channels on the basis of the similar properties of $\mathrm{Cl}^{-}$currents under isotonic and hypotonic conditions. Pharmacologic inhibition of volume-activated $\mathrm{Cl}^{-}$channels reduced migration of glioma cells through $8 \mu \mathrm{m}$ pores. Our data are consistent with the hypothesis that volume-activated $\mathrm{Cl}^{-}$channels contribute to the shape-volume changes required for movement of glioma cells through narrow migratory pathways. The resting $\mathrm{Cl}^{-}$conductance may be a positive adaptation that contributes to the invasive behavior of glioma cells.

\section{REFERENCES}

Adams RD, Victor M (1989) Principles of neurology, Ed 4. New York: McGraw-Hill.

Bakhramov A, Fenech C, Bolton TB (1995) Chloride current activated by hypotonicity in cultured human astrocytoma cells. Exp Physiol 80:373-389.

Basarsky TA, Feighan D, MacVicar BA (1999) Glutamate release through volume-activated channels during spreading depression. J Neurosci 19:6439-6445.

Belien ATJ, Paganetti PA, Schwab ME (1999) Membrane type-1 matrix metalloprotease (MT1-MMP) enables invasive migration of glioma cells in central nervous system white matter. J Cell Biol 144:373-384.

Bond TD, Ambikapathy S, Mohammed S, Valverde MA (1998a) Osmosensitive $\mathrm{Cl}^{-}$currents and their relevance to regulatory volume decrease in human intestinal T84 cells: outwardly vs. inwardly rectifying currents. J Physiol (Lond) 511:45-54.

Bond TD, Valverde MA, Higgins CF (1998b) Protein kinase C phosphorylation disengages human and mouse 1a-P-glycoproteins from influencing the rate of activation of swelling-activated chloride currents. J Physiol (Lond) 508:333-340.

Bordey A, Sontheimer H (1997) Postnatal development of ionic currents in rat hippocampal astrocytes in situ. J Neurophysiol 78:461-477.

Brismar I, Collins VP (1988) Inward K-current in human malignant glioma cells: possible mechanism for K-homeostasis in the brain. Acta Physiol Scand 132:259-260.

Brundage RA, Fogarty KE, Tuft RA, Fay FS (1991) Calcium gradients underlying polarization and chemotaxis of eosinophils. Science 254 : 703-706.

Cone CD (1970) Variation of the transmembrane potential level as a basic mechanism of mitosis control. Oncogenesis 24:438-470.

Crepel V, Panenka W, Kelly ME, MacVicar BA (1998) Mitogenactivated protein and tyrosine kinases in the activation of astrocyte volume-activated chloride current. J Neurosci 18:1196-1206.

Danker T, Gassner B, Oberleithner H, Schwab A (1996) Extracellular detection of $\mathrm{K}^{+}$release during migration of transformed Madin-Darby canine kidney cells. Pflügers Arch 433:71-76.

Diaz M, Valverde MA, Higgins CF, Rucareanu C, Sepulveda FV (1993) Volume-activated chloride channels in HeLa cells are blocked by verapamil and dideoxyforskolin. Pflügers Arch 422:347-353.

Duan D, Winter C, Cowley S, Hume JR, Horowitz B (1997) Molecular identification of a volume-activated chloride channel. Nature 390:417-421.

Duan D, Cowley S, Horowitz B, Hume JR (1999) A serine residue links phosphorylation-dephosphorylation to chloride channel regulation by cell volume. J Gen Physiol 113:57-70.

Hamill OP, Marty A, Neher E, Sakmann B, Sigworth FJ (1981) Improved patch-clamp techniques for high-resolution current recording from cells and cell-free membrane patches. Pflügers Arch 391:85-100.

Hille B (1992) Ionic channels of excitable membranes. Sunderland, MA: Sinauer.

Imai K, Tatsumi H, Katayama Y (2000) Mechanosensitive chloride channels on the growth cones of cultured rat dorsal root ganglion neurons. Neuroscience 97:347-355.

Jackson PS, Madsen JR (1997) Cerebral edema, cell volume regulation, and the role of organic osmolyte transport. Pediatr Neurosurg 27:279285.

Kettenmann H, Sonnhof U, Schachner M (1983) Exclusive potassium dependence of the membrane potential in cultured mouse oligodendrocytes. J Neurosci 3:500-505.

Kirk KL (1997) Swelling-activated organic osmolyte channels. J Membr Biol 158:1-16.

Kofuji P, Ceelen P, Zahs KR, Surbeck LW, Lester HA, Newman EA (2000) Genetic inactivation of an inwardly rectifying potassium channel (Kir4.1 subunit) in mice: phenotypic impact in retina. J Neurosci 20:5733-5740.

Komuro H, Rakic P (1996) Intracellular Ca2+ fluctuations modulate the rate of neuronal migration. Neuron 17:275-285.

Lang F, Busch GL, Ritter M, Volkl H, Waldegger S, Gulbins E, Haussinger D (1998) Functional significance of cell volume regulatory mechanisms. Physiol Rev 78:247-306.

Lascola CD, Kraig RP (1996) Whole-cell chloride currents in rat astrocytes accompany changes in cell morphology. J Neurosci 16:2532-2545.

Lascola CD, Nelson DJ, Kraig RP (1998) Cytoskeletal actin gates a $\mathrm{Cl}^{-}$ channel in neocortical astrocytes. J Neurosci 18:1679-1692.

MacLeod RJ, Hamilton JR (1999) Increases in intracellular $\mathrm{pH}$ and $\mathrm{Ca}^{2+}$ are essential for $\mathrm{K}^{+}$channel activation after modest "physiological" swelling in villus epithelial cells. J Membr Biol 172:47-58.

Maduke M, Miller C, Mindell JA (2000) A decade of CLC chloride channels: structure, mechanism, and many unsettled questions. Annu Rev Biophys Biomol Struct 29:411-418.

Maidment SL (1997) The cytoskeleton and brain tumour cell migration. Anticancer Res 17:4145-4149.

Mignen O, Le Gall C, Harvey BJ, Thomas S (1999) Volume regulation following hypotonic shock in isolated crypts of mouse distal colon. J Physiol (Lond) 512:501-510.

Newman EA (1993) Inward-rectifying potassium channels in retinal glial (Muller) cells. J Neurosci 13:3333-3345.

Nilius B, Sehrer J, De Smet P, Van Driessche W, Droogmans G (1995) Volume regulation in a toad epithelial cell line: role of coactivation of $\mathrm{K}^{+}$and $\mathrm{Cl}^{-}$channels. J Physiol (Lond) 487:367-378.

O'Connor ER, Kimelberg HK (1993) Role of calcium in astrocyte volume regulation and in the release of ions and amino acids. J Neurosci $13: 2638-2650$.

O'Grady SM, Jiang X, Ingbar DH (2000) $\mathrm{Cl}^{-}$channel activation is necessary for stimulation of $\mathrm{Na}$ transport in adult alveolar epithelial cells. Am J Physiol 278:L239-L244.

Pappas CA, Ritchie JM (1998) Effect of specific ion channel blockers on cultured Schwann cell proliferation. Glia 22:113-120.

Pasantes-Morales H, Murray RA, Lilja L, Moran J (1994) Regulatory volume decrease in cultured astrocytes. I. Potassium- and chlorideactivated permeability. Am J Physiol 266:C165-71.

Phillis JW, Song D, O'Regan MH (1998) Tamoxifen, a chloride channel blocker, reduces glutamate and aspartate release from the ischemic cerebral cortex. Brain Res 780:352-355.

Picker S, Pieper CF, Goldring S (1981) Glial membrane potentials and their relationship to $\left[\mathrm{K}^{+}\right]_{\mathrm{o}}$ in man and guinea pig. J Neurosurg 55:347363.

Pollard CE (1993) A volume-sensitive $\mathrm{Cl}^{-}$conductance in a mouse neuroblastoma X rat dorsal root ganglion cell line (F11). Brain Res 614:178-184.

Rae J, Cooper K, Gates P, Watsky M (1991) Low access resistance perforated patch recordings using amphotericin b. J Neurosci Methods $37: 15-26$

Ransom CB, Sontheimer H (1995) Biophysical and pharmacological characterization of inwardly rectifying $\mathrm{K}^{+}$currents in rat spinal cord astrocytes. J Neurophysiol 73:333-345.

Ransom CB, Sontheimer H (2001) BK channels in human glioma cells. J Neurophysiol 85:790-783.

Rasola A, Galietta LJV, Greunert DC, Romeo G (1992) Ionic selectivity 
of volume-sensitive currents in human epithelial cell. Biochim Biophys Acta 1139:319-323.

Rouzaire-Dubois B, Dubois JM (1998) $\mathrm{K}^{+}$channel block-induced mammalian neuroblastoma cell swelling: a possible mechanism to influence proliferation. J Physiol (Lond) 510:93-102.

Rouzaire-Dubois B, Bostel S, Dubois JM (1999) Evidence for several mechanisms of volume regulation in neuroblastoma $\mathrm{x}$ glioma hybrid NG108-15 cells. Neuroscience 88:307-317.

Roy G (1995) Amino acid current through anion channels in cultured human glial cells. J Membr Biol 147:35-44.

Schneider SW, Pagel P, Rotsch C, Danker T, Oberleithner H, Radmacher M, Schwab A (2000) Volume dynamics in migrating epithelial cells measured with atomic force microscopy. Pflügers Arch 439:297-303.

Schwab A, Schuricht B, Seeger P, Reinhardt J, Dartsch PC (1999) Migration of transformed renal epithelial cells is regulated by $\mathrm{K}^{+}$channel modulation of actin cytoskeleton and cell volume. Pflügers Arch 438:330-337.

Shen MR, Droogmans G, Eggermont J, Voets T, Ellory JC, Nilius B (2000) Differential expression of volume-regulated anion channels during cell cycle progression of human cervical cancer cells. J Physiol (Lond) 529:385-394.

Soroceanu L, Manning TJ, Sontheimer H (1999) Modulation of glioma cell migration and invasion using $\mathrm{Cl}^{-}$and $\mathrm{K}^{+}$ion channel blockers. J Neurosci 19:5942-5954.

Sorota S (1995) Tyrosine protein kinase inhibitors prevent activation of cardiac swelling-induced current. Pflügers Arch 431:178-185.

Stobrawa S, Breiderhoff T, Takamori S, Engel D, Schweizer M, Zdebik AA, Bosl MR, Ruether K, Jahn H, Draguhn A, Jahn R, Jentsch T (2001) Disruption of ClC-3, a chloride channel expressed on synaptic vesicles, leads to loss of the hippocampus. Neuron 29:185-196.

Strange K (1988) RVD in principal and intercalated cells of rabbit cortical collecting tubule. Am J Physiol 255:C612-C621.

Trouet D, Nilius B, Jacobs A, Remacle C, Droogmans G, Eggermont J (1999) Caveolin-1 modulates the activity of the volume-regulated chloride channel. J Physiol (Lond) 520:113-119.
Ullrich N, Sontheimer H (1996) Biophysical and pharmacological characterization of chloride currents in human astrocytoma cells. Am J Physiol 270:C1511-C1521.

Ullrich N, Bordey A, Gillespie GY, Sontheimer H (1998) Expression of voltage-activated chloride currents in acute slices of human gliomas. Neuroscience 83:1161-1173.

Valverde MA (1999) CLC channels: leaving the dark ages on the verge of a new millenium. Curr Opin Cell Biol 11:509-516.

Valverde MA, Mintenning GM, Sepulveda FV (1994) $\mathrm{Cl}^{-}$currents of unstimulated T84 intestinal epithelial cells studied by intracellular recording. J Membr Biol 137:237-247.

Venglarik CJ, Bridges RJ, Frizzell RA (1990) A simple assay for agonist-regulated $\mathrm{Cl}$ and $\mathrm{K}$ conductances in salt-secreting epithelial cells. Am J Physiol 259:C358-C364.

Von Weikersthal SF, Barrand MA, Hladky SB (1999) Functional and molecular characterization of a volume-sensitive chloride current in rat brain endothelial cells. J Physiol (Lond) 516:75-84.

Wang L, Chen L, Jacob TJ (2000) The role of ClC-3 in volume-activated chloride currents and volume regulation in bovine epithelial cells demonstrated by antisense inhibition. J Physiol (Lond) 524:63-75.

Wilson GF, Chiu SY (1993) Mitogenic factors regulate ion channels in Schwann cells cultured from newborn rat sciatic nerve. J Physiol (Lond) 470:501-520.

Worrell RT, Butt AG, Cliff WH, Frizzell RA (1989) A volume-sensitive chloride conductance in human colonic cell line T84. Am J Physiol 256:C1111-C1119.

Xiong H, Li C, Garami E, Wang Y, Ramjeesingh M, Galley K, Bear CE (1999) ClC-2 activation modulates regulatory volume decrease. J Membr Biol 167:215-221.

Ye ZC, Sontheimer H (1999) Glioma cells release excitotoxic concentrations of glutamate. Cancer Res 59:4383-4391.

Ye ZC, Rothstein JD, Sontheimer H (1999) Compromised glutamate transport in human glioma cells: reduction-mislocalization of sodiumdependent glutamate transporters and enhanced activity of cystineglutamate exchange. J Neurosci 19:10767-10777. 